\title{
DETERMINANTS OF INDONESIAN CRUDE PALM OIL EXPORT: GRAVITY MODEL APPROACH
}

\author{
Ridwannulloh, Sunaryati \\ Fakultas Ekonomi dan Bisnis Islam, Universitas Islam Negeri Sunan Kalijaga Yogyakarta, \\ Jl. Laksda Adisucipto, Caturtunggal, Depok, Sleman, Daerah Istimewa Yogyakarta 55281 \\ Correspondence E-mail: riduandatsmile@gmail.com
}

Received: August 2018; Accepted: October 2018

\begin{abstract}
Crude Palm Oil (CPO) is a commodity in the agricultural sector with the largest contribution to the value of Indonesian exports. Moreover, since 2006, Indonesia has become the largest CPO producer in the world. Therefore, this research attempts to investigate determinants of Indonesia CPO export to main trading partners using Gravity model approach. This study is conducted to analyze the effect of Indonesia's GDP, GDP of Indonesia's four main trading partners, distance, the rupiah exchange rate against $U S$ dollar and domestic CPO consumption on Indonesian CPO exports. The analysis technique is used in this research is panel data regression using fixed effect model. The results of this study indicate that not all variables have significant effects on Indonesian CPO exports. Variables such as Indonesia's GDP and GDP of major trading partners have positive and significant effect, whereas rupiah exchange rate variable and domestic consumption have negative and significant effect on Indonesian CPO export. In addition, in line with Gravity model, variable of distance has negative and significant effect on Indonesian CPO exports.
\end{abstract}

Keywords: CPO Exports, Growth Domestic Product, Gravity Model, Panel Data

JEL Classification: F10, F11, F12

\section{INTRODUCTION}

Indonesia is one of the countries applying open economy system. An implications of open economy is observed from the use of international trade to increase the economic growth (Dumairy, 1996). Besides, international trade is one of the ammunitions to stimulate the growth of domestic trade (Dodzin and Vamvakidis, 2004). A country is trading to others with two main reasons, the first is to acquire gain form trade and the second is to obtain the economics of scale. (Krugman, 2004). There are two main variables that should be considered in international trade such as export and import. Export is national production which consumed for other countries while import is foreign product consumed nationally (Basri et al., 2010). According to Labor Statistics Bureau (2018), Indonesian export in 2016 is approximately \$US 145.18 bil- lion, comprise of non-oil and gas at about \$US 132.08 billion and oil and gas export at amount \$US 13.10 billion.

Plantation is a prominent component from non-oil sector. Plantation sector and gas sector are important and these sectors become supporting sources for Indonesia's, both income and foreign exchange. Based on the data from the Ministry of Agricultural, during 2016, Indonesian commodity export reaches 34.62 million ton or equal to \$US 25.53 billion, leads to high contribution into our export which around $17.11 \%$ from total (Directorate General of Plantation, 2017). Palm oil is one of the commodities that gives the highest contribution to export. Based on Association of Palm Oil Farmer or (GAPKI) in 2006, Indonesia is the largest palm oil distributor followed by Malaysia in second place. 


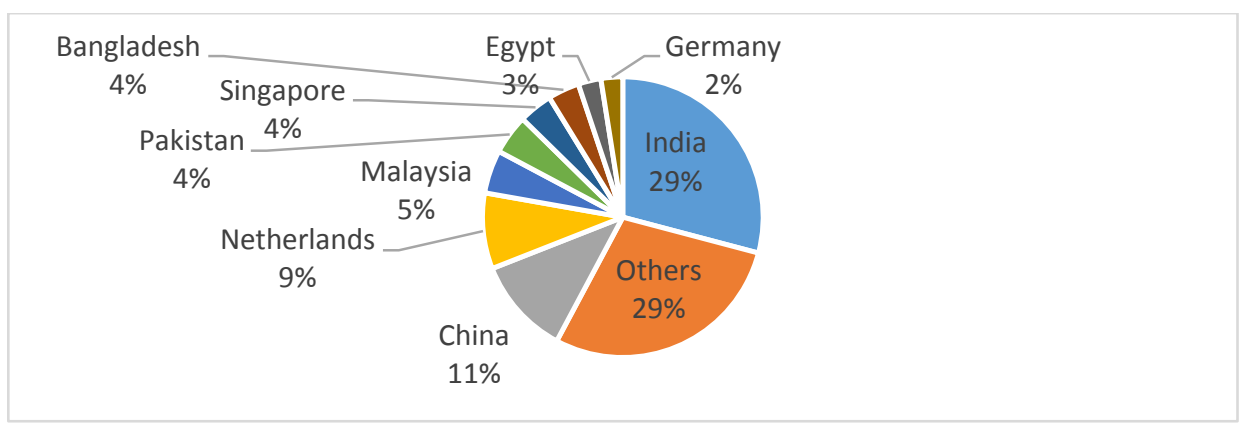

Source: Labor of Statistics Bureau (2018)

\section{Figure 1. Primary Exported Countries CPO to Total of Indonesian CPO Export}

Palm oil sector not only as foreign exchange contributor but also could hire many potential workers during its production. The production of palm oil in Indonesia mostly to be exported, only $20 \%-30 \%$ is used domestically. Based on data from Bureau Labor of Statistics (2018) with the average growth of export is $11.22 \%$ per year, the CPO export has grown from 6.33 million ton in 2002 to 24.46 million ton in 2015. On the average, the $\mathrm{CPO}$ export in Indonesia is amount $74.70 \%$.

Based on figure 1, it can be seen that Indonesia has 10 main importing countries. India is Indonesia's the biggest importing countries with an average contribution of $29.15 \%$ from the total of Indonesia's CPO export. Then followed by China, and India in the next place, with an average contribution of $11.04 \%$ annually. Malaysia and The Netherlands are in the third and fourth place with an average contribution $9 \%$ and $5.08 \%$ respectively. All four countries contributions to Indonesia's CPO export is about $54.27 \%$ of total Indonesia's CPO export.

This research aims to analyze the impact from GDP, CPO domestic consumption, IDR exchange rate against $\$ \mathrm{US}$, the distance of Indonesia with four trading partners. This research is using Gravity model, a model that is developed by Tinbergen (1962), this research attempts to analyze the effect of distance of four main trading partner countries using multiple regression method with fixed effect model. According to Salvatore (2014), a country generally pick bigger country (by bigger GDP amount) as a trading partner compared to smaller country, a country with the closer distance avoiding the high cost of transportation, with open economic country rather than closed economic country, with almost similar background rather than one without similar background.

Gravity model has a basic notion which states that the bilateral trade between two countries will be positively correlated with GDP from two countries and the closer the distance of two countries (if all other things are held constant). The higher the economics of scale, the closer the distance is, then the volume of trading shall be higher (Salvatore, 2007). The construction of this theory is coined from GravIty Law created by Issac Newton on Physics discipline.

Principles of Political Economy and Taxation (Ricardo, 1817) which is explained the law of comparative absolute advantage, this theory is one of the most important law in the international trade to face any challenges in any trade practices (Salvatore, 2014). According to the law of comparative absolute advantage, if one country is not efficient enough towards theother country on producing certain commodity, but it should be making good for both countries. The first country should specialize in producing and exporting commodity which has less absolute loss and importing commodity which has a more absolute loss (Salvatore, 2014). 
The main source of international trade is the difference in resources having by each country that affected international trade (Krugman, 2004). This theory is developed by two prominent economists from Sweden, Eli Heckscher dan Bertil Ohlin thus it is famously known as Heckscher-Ohlin theory. It is also known as factor proportion theory and endowment factor theory. This is because the two theories emphasize in the difference of proportion factor on each country and the difference used in producing any goods (Krugman, 2004). Gross Domestic Product (GDP) is the total value of all goods and services produced by one country in a certain period of time (Mankiw, 2014). GDP calculation can be calculated using three approaches, which is expenditure approach, production approach and income approach (Trenggonowati, 2010).

Our exchange rate between two countries is the price where the people is exchanging goods (Mankiw, 2014). The economists are dividing the exchange rate to real and nominal exchange rate. Nominal exchange rate is the relative price from the two currencies. Real exchange rate is the relative price from goods in each country. It is also known as terms of trade. The real exchange rate is calculated from total of nominal exchange rate and price rate in two countries. There is a significant negative relationship between exchange rate and export.

\section{RESEARCH METHOD}

\section{Data and Source}

The analysis method that is used in this research is quantitative method with regression analysis tools taken from panel data during 1995-2016. The sample data from this research is taken from the four primary trading partners, such as India, the Netherlands, Malaysia and China. The variables data are GDP, exchange rate, domestic consumption, and the distance between two capital cities of two countries. The data source are from; World Development Indicators World Bank for exchange rate and GDP.
While CPO export data is taken from Indonesia Bureau of Statistics, production and consumption of Indonesian $\mathrm{CPO}$ data is taken from Directorate General of Plantation. The distance variable is using Google Maps in which point the distance between two countries.

\section{Operational Variables Definition}

On this research, the variables are divided into two groups; dependent and independent variable. The dependent variable is Export $\mathrm{ij}=$ the value of Indonesian CPO export to four primary trading partner (\$US million), while the independent variable is $\mathrm{GDP}_{\mathrm{i}}=$ Indonesian GDP (\$US million), GDP $_{j}=$ GDP from four countries (\$US million). GDP is the arrow point for estimation on gravity model, because it depicts the demand and supply as a whole (Tinbergen \& Hekscher, 1962). CONS i = domestic consumption on Indonesian $\mathrm{CPO}$ (million ton), Exchange rate = rupiah exchange rate (IDR/\$US), DIST = distance between two capital cities measured by the formula (Li et al., 2008).

\section{Analysis Tool}

The analysis tool used in this research is multiple linear regressions with panel data. One of the advantages using this tool is minimize heterogeneity explicitly and give variable a specific subject. Other advantages would be, give more information, add more variation and minimize collinearity among variables, thus much more efficient (Gujarati, 2010). After deciding which model is the best among the common effect model, random effect model, or fixed effect model, the next step is to test statistically with $t$ test and $F$ test, as well with coefficient determination $\left(\mathrm{R}^{2}\right)$. The below is the equation used in this research as indicated in equation (1),

$$
\begin{aligned}
X_{i j}=\alpha+\beta_{1} G D P_{i} & +\beta_{2} G D P_{j}+\beta_{3} C O N S+\beta_{4} K_{U R S} \\
& +\beta_{5} D I S T A N C E \\
& +\epsilon \ldots \ldots \ldots \ldots \ldots \ldots \ldots \ldots \ldots \ldots \ldots \ldots \ldots \ldots \ldots \ldots \ldots \ldots \ldots
\end{aligned}
$$

Log-linear equation decides that the trend from $i$ to $j$ can be explained from economic 
power from its and to source (Bergstrand, 1985). Thus, the equation can be transformed to this log-linear equation is presented in equation (2),

$$
\begin{aligned}
\ln X_{i j}=\alpha+\beta_{1} & \operatorname{lnGDP_{i}}+\beta_{2} \operatorname{lnGDP} P_{j}+\beta_{3} \operatorname{lnCONS} \\
& +\beta_{4} \ln K U R S_{j}+\beta_{5} \ln D I S T A N C E \\
& +\epsilon \ldots \ldots \ldots \ldots \ldots \ldots \ldots \ldots \ldots \ldots \ldots \ldots \ldots \ldots \ldots \ldots \ldots \ldots \ldots
\end{aligned}
$$

Where,

$\ln X_{\mathrm{ij}} \quad=$ Log of Indonesian CPO Export

$\operatorname{lnGDPi} \quad=$ Log of Indonesian GDP

$\operatorname{lnGDPj}=$ Log of GDP from trading partners

$\operatorname{lnCONSi}=$ Indonesia Consumption of Domestic Indonesian CPO

$\operatorname{lnKURSi}=$ Exchange rate IDR against US\$ lnDISTANCE $=$ Distance between country $\mathrm{i} \& \mathrm{j}$

\section{RESULT AND DISCUSSION}

Based on the estimation from random effect model and fixed effect model lead to a result in which can be an estimator. Thus, it is needed to pick the best model by doing some of the test.

\section{Chow Test}

Chow test is used to select the most appropriate model to analyze the panel data between pooled least square and fixed effect. The result of chow test can be seen from table 1 .

Table 1. The Result of Chow test or Likelihood Ratio Test

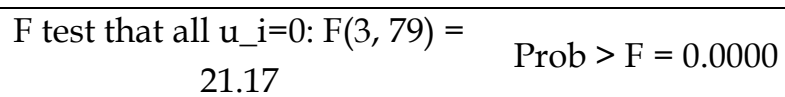

Source: Author Estimation, using Stata14

The criteria from Chow test is that if $\mathrm{F}$ probability less than $5 \%$ degree conclude to reject $\mathrm{H}_{0}$ or proved that fixed effect model is more appropriate than pooled least square model. Based on Chow test from the above, we can get the result that the F probability is $F=0.0000$ or less than a (0.01). $\mathrm{H}_{0}$ is rejected and the most appropriate model that can be used is fixed effect model.

\section{Hausman Test}

Hausman test is done to choose the most appropriate model in analyzing panel data between fixed-effect-model and random-effectmodel. The result from Hausman test can be seen on table 2,

Table 2. The Result of Hausman Test $\mathrm{Chi}^{2}(5)=(\mathrm{b}-\mathrm{B})^{\prime}\left[\left(\mathrm{V} \_\mathrm{b}-\mathrm{V} \_\mathrm{B}\right)^{\wedge}(-1)\right](\mathrm{b}-\mathrm{B})=13.36$ Prob $>\mathrm{Chi}^{2}=0.0202$

(V_b-V_B is not positive definite) Source: Author estimation with Stata14, 2018

The criteria from Hausman test is that if the probability of Chi-square is less than the degree of $5 \% . \mathrm{H}_{0}$ is accepted or it can be said that fixed effect model is more appropriate than random effect model. According to the result of Hausman test on the above, it is stated that Probability of Chi-square is 0.0202 or less than a (0.05). $\mathrm{H}_{0}$ is accepted, then fixed effect model is being used on this research.

\section{Lagrange Multiplier Test}

Lagrange multiplier test is done to point which model is the most appropriate on analyzing panel data between random effect model and common-effect-model. The result can be seen on table 3 as follow,

Table 3. The Result of Lagrange Multiplier

\begin{tabular}{lll}
${\overline{C h \iota^{2}}}^{2}(01)$ & $=$ & 65.76 \\
Prob $>\overline{C h l}^{2}$ & $=$ & 0.0000 \\
\hline
\end{tabular}

Source: Author estimation with Stata14, 2018

The criteria from Lagrange multiplier test is that if probability of Chi-square is less than the $5 \%$ degree, so $\mathrm{H}_{0}$ is accepted, or it is proven that random effect model is more appropriate to be used than the common effect model. Based on Lagrange multiplier test result in table 4, the Probability of Chi-square is 0.0000 or less than a (0.05). $\mathrm{H}_{\mathrm{o}}$ is accepted and random effect model is chosen.

From Chow test, Hausman test and Lagrange multiplier test we can conclude that the most appropriate model to use on this research is fixed effect model. 
Table 4. Panel Regression Result using Fixed Effect Model

\begin{tabular}{lccc}
\hline \multicolumn{1}{c}{ Variable } & Coef. & Std. Err. & P>t \\
\hline lnGDPi & 1.98661 & 1.11884 & $0.07970^{*}$ \\
lngGDPj & 2.59407 & 0.50952 & $0.00000^{* * *}$ \\
lnKURS & -0.02763 & 0.18681 & 0.88280 \\
lnDISTANCE & -0.00447 & 0.00199 & $0.02730^{* *}$ \\
lnCONS & -0.34789 & 0.79668 & 0.66350 \\
cons & -101.11099 & 25.26833 & $0.00010^{* * *}$ \\
R2 & & 0.77137 & \\
Adj R2 & & 0.74822 & \\
Prob F & & 0.00000 & \\
N & & 88 & \\
legen & & &
\end{tabular}

legend: ${ }^{*} \mathrm{p}<0.1 ;{ }^{* *} \mathrm{p}<0.05 ;{ }^{* * *} \mathrm{p}<0.01$

a. The Influence of Indonesian GDP and Four Primary Trading Partners toward Indonesia CPO Export Value

The regression coefficients of GDP and four GDP of four main trading partners are 1.1188441 and 0.5095222. Partially, the $t$ probability is $0.079(<\alpha 0.1)$ and $0.000(<\alpha$ $0.01)$, thus Indonesian GDP and GDP of 4 trading partners positively impact toward Indonesia CPO export value. Thereby the first hypothesis on this research is accepted.

The result is supported by the previous research conducted by (Yuniarti, 2007) which stated that the GDP from the exporter countries is positively affected Indonesian export value. Another research performed by (Egger, 2000) also shows the positive relationship between GDP and export volume.

Research from (Kalbasi, 2001) GDP of exporter countries measure the production capacity of the countries, the higher the GDP are, the more commodities they could produce. In addition, GDP of importing countries measure the absorption capacity. The increasing amount from GDP of importer countries leads to higher absorption capacity. The finding implicates to increase the production the GDP from each country should always be increased. According to (Yuniarti, 2007) the decent situation of global economic is highly needed to lead the trading.

The result is also strongly supported by the hypothesis of growth driven export which shows that the economic growth impacts on the trade. It will lead to comparative advantage in certain areas and will give its specialization to the country. The main qualification for a country to export goods is to create the decent situation that will result in a continuously economic growth (Haryati \& Hidayat, 2015).

Based on research from (Lee \& Huang, 2002) the growth of a country's output will increase the export growth. When an economy is growing, thus a number of sectors will face a big change in terms of technology and innovation that links to human resource, transfer of technology or capital accumulation. In end, the output from one country is exceeding and has excess supply in turn the supply will be sold in other countries.

b. The Impact of Exchange Rate towards Indonesian CPO Export Value

The result from the regression coefficient of exchange rate is -0.02762789 and partially the probability of $t$ value is 0.88 ( $>$ a 0.05$)$. This, we can say that exchange rate is negatively affected to USD is negatively and insignificantly affected toward $\mathrm{CPO}$ 
export value of four trading partner. The second hypothesis is rejected.

The former researcher (Azizah, 2015) indicates that exchange rate has a negative and significant impact on the value of Indonesian CPO export. Other results come from (Huda, 2017) dan (Ginting, 2013) state that exchange rate has a negative and significant impact on Indonesian export. On the researches exchange rate has a two-way relationship on international $\mathrm{CPO}$ trade, meaning when an exchange rate depreciates, while export increases and vice versa.

The finding helps to strengthen the relationship between exchange rate and export-import. If Rupiah appreciates toward forex, it will reduce the export value while import will increase. It happens because the domestic goods in international market become much more expensive (Huda, 2017).

c. The Impact of Domestic Consumption on Indonesian Export Value

The estimation result shows the coefficient regression value of domestic consumption of -0.34788871 with $\mathrm{t}$ probability of 0.66 ( $>$ a 0.05 ). It can be concluded that domestic consumption will negatively impact the export value. It is also insignificantly affected toward the CPO export value. Thus, the third hypothesis is rejected.
Based on the data from GAPKI, Indonesian $\mathrm{CPO}$ is an export commodity so the $\mathrm{CPO}$ domestic consumption will not significantly affected toward Indonesian CPO export. The domestic consumption of Indonesian CPO is only counted for $30 \%$ from total production. In other words, $70 \%$ of Indonesian CPO production is to be exported not for domestic consumption.

Indonesian domestic $\mathrm{CPO}$ consumption is much lower from the total production and $\mathrm{CPO}$ export. However, the volume of domestic consumption each year is increasing. The domestic consumption encompasses biodiesel, soap, and detergent (GAPKI, 2017). The CPO production mostly intended to be exported, only $20-30 \%$ used for domestic consumption. With an average export growth of 11-12\% yearly, Indonesian $\mathrm{CPO}$ export has experienced an increasing growth from 2002 which only 6.33 million ton to 24.64 million ton in 2015. The average of Indonesian CPO export is 14.76 million ton or $74.70 \%$ of the total production.

d. The Influence of Economic Distance on Indonesian CPO Export Value

From the estimation, the value of distance is -0.0047055 with $\mathrm{t}$ probability of 0.0273 ( $<a 0.05)$. Thus this variable is negatively and significantly affected the export value. Consequently, the fourth hypothesis is accepted.

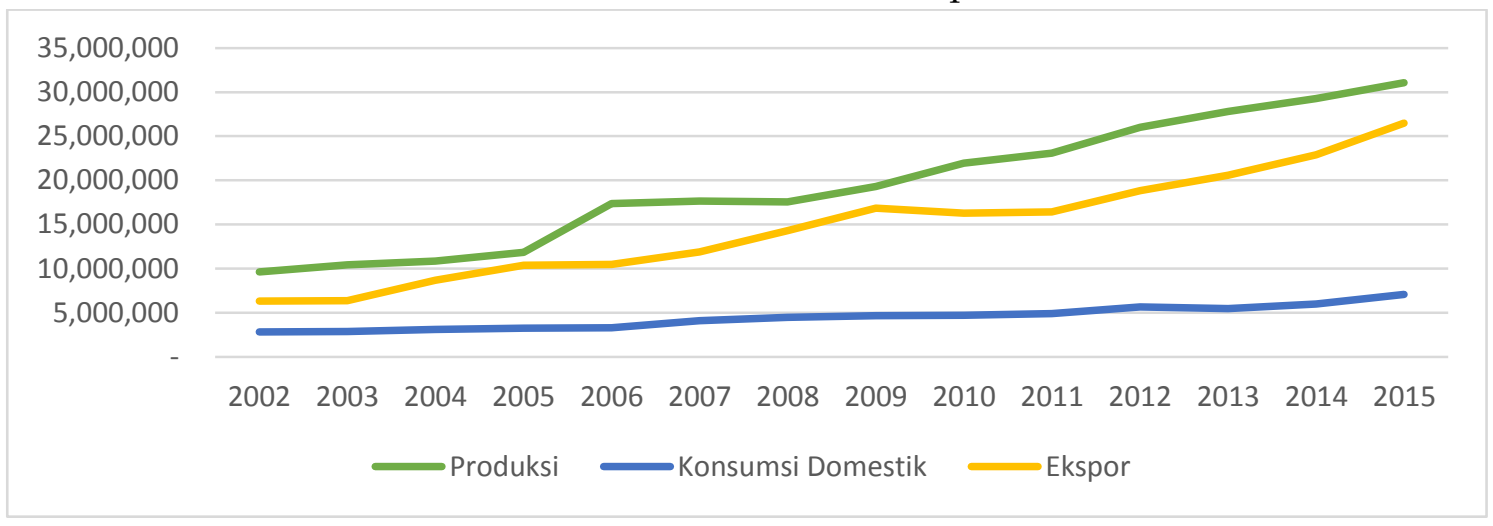

Figure 2. Consumption and Indonesian CPO Export

Source: Directorate General of Plantation (2016) 
The result is supported by other researches from (Rahman, 2009), (Sitorus, 2009) and (Yuniarti, 2007) note that, the far distance it gets between the importer and exporter country will lead to the reduction of CPO export because of the high transportation cost.

\section{CONCLUSION}

Based on the research, we can conclude on the below:

1. All countries GDP variables are significantly affected toward Indonesian CPO export. This shows that GDP from exporter countries will measure the production rate, the higher GDP is, the more production it can produce. While GDP from importer countries is measuring the absorption capacity. This finding implicated that to reach the high trade volume needs to increase the capacity from each country. Another thing we can see is the decent situation of global trade is highly needed to increase the international trade value.

2. IDR exchange rate against $\$ \mathrm{US}$ has negative and insignificant effects on Indonesian $\mathrm{CPO}$ export value. In this research, the relationship between IDR exchange rate and CPO has a two-way relationship.

3. The effect of domestic consumption is negative and insignificant on Indonesian $\mathrm{CPO}$ export value. The consumption is much lower compared to the production and exported CPO. As a result, we can see the increasing domestic consumption per year which encompasses some industries, only $20-30 \%$ production is used for domestic consumption.

4. The distance variable has negative and significant effects on Indonesian $\mathrm{CPO}$ export value. The more distance of country importers, the CPO export reduces to some degrees because of the higher transportation cost.
If there is a takeaway from this research, it would be for all the linked institutions such as, Directorate General of Plantation, GAPKI, monetary authority or government that is expected to notice the movement of indicated variables on export value of Indonesian CPO. For monetary authority it is expected to have the tight inspection on IDR fluctuations that give an impact on Indonesian CPO. In addition, the government needs to conduct proactive policy to stimulate $\mathrm{CPO}$ production to become readygoods or half-ready goods in order not merely rely on $\mathrm{CPO}$ export.

\section{REFERENCES}

Azizah, N. (2015). Analisis Ekspor Crude Palm Oil (CPO) Indonesia di Uni Eropa Tahun 2000-2011. Economics Development Analysis Journal, 4(3), 301-307.

Basri, Faisal dan Munandar, H. (2010). Dasardasar Ekonomi Internasional. Jakarta: Kencana.

Bergstrand, J. H. (1985). The Gravity Equation in International Trade: Some Microeconomic Foundations and Empirical Evidence. The Review of Economics and Statistics, 67(3), 474. https:// doi.org/10.2307/1925976

Directorate General of Plantation (2017). http://epublikasi.setjen.pertanian.go.id/e publikasi/outlook/2017/Outlook\%20Kela pa\%20Sawit $\% 202017 /$ files/assets/basic$\mathrm{html} /$ page73.html, retrieved on 30 October 2018 .

Dodzin, S., and Vamvakidis, A. (2004). Trade and industrialization in developing economies. Journal of Development Economics, 75(1), 319-328. https://doi.org/10.1016/j.jdeveco.2003.08. 006

Dumairy. (1996). Perekonomian Indonesia. Jakarta: Erlangga.

Egger, P. (2000). A Note on the Proper Econometric Specification of the Gravity 
Model. Economics Letters, 66(1), 25-31. https://doi.org/10.1016/S0165-

1765(99)00183-4

Ginting, A.M. (2013). Pengaruh Nilai Tukar Terhadap Ekspor Indonesia. Buletin Ilmiah Litbang Perdagangan, 7(1), 1-18.

Gujarati, D.N. (2010). Dasar-Dasar Ekonometrika, Edisi Kelima. Jakarta: Salemba Empat.

Haryati, S.N., dan Hidayat, P. (2015). Analisis Kausalitas Antara Ekspor Dan Pertumbuhan Ekonomi Di Asean Plus Three. Ekonomi Dan Keuangan, 2(6), 336352.

Huda, E.N. (2017). Determinan Dan Stabilitas Ekspor Crude Palm Oil Indonesia. Jurnal Ekonomi dan Bisnis, 20(1), 45-66.

Kalbasi, H. (2001). The Gravity Model and Global Trade Flows. In 75th International Conference on Policy Modeling for European and Global Issues, Brussels. July, 5-7.

Krugman, P.R. (2004). Ekonomi Internasional, Teori dan Kebijakan. Jakarta: Indeks.

Lee, C.H., and Huang, B.N. (2002). The Relationship Between Exports and Economic Growth In East Asian Countries: A Multivariate Threshold Autoregressive Approach. Journal of Economic Development, 27(2), 45-68.

Li, K., Song, L., Zhao, X. (2008). Component Trade and China's Global Economic Integration. United Nations University, World Institute for Development Economics Research.

Mankiw, N.G. (2014). Pengantar Ekonomi Makro: Edisi Asia. Jakarta: Salemba Empat.

Rahman, M.M. (2009). Australia's Global Trade Potential: Evidence from the Gravity Model Analysis. Oxford Business $\mathcal{E}$ Economics Conference Program. Retrieved from

https://eprints.usq.edu.au/5537/1/Rahm an_OBEC_09_PV.pdf

Ricardo, D. (1817). Principles of Political Economy and Taxation. London: John Murray, Albe-
marle-Street.

Salvatore, D. (2014). Ekonomi Internasional Edisi Kesembilan Buku 1. Jakarta: Salemba Empat.

Sitorus, M. (2009). Peningkatan Ekspor CPO dan Kakao Di Bawah Pengaruh Liberalisasi Perdagangan (Suatu Pendekatan Model Gravitasi). Institut Pertanian Bogor.

Tinbergen, J., and Hekscher, A. (1962). Shaping the World Economy. Suggestions for an International Economic Policy [With Forew. Bf A. Hekscher]. Twentieth Century Fund.

Trenggonowati. (2010). Teori Makroekonomi. Yogyakarta: BPFE UGM.

Yuniarti, D. (2007). Analisis Determinan Perdagangan Bilateral Indonesia Pendekatan Gravity Model. Jurnal Ekonomi Pembangunan Kajian Ekonomi Negara Berkembang, 2(12), 99-109. 